\title{
Effects of wastewater characteristics on fish quality from integrated wastewater treatment system and fish farming in Urban Areas, Tanzania
}

\author{
Ahamdi Habibu Mkali, Jasper Ijumba, Karoli Nicholas Njau \\ Department of Water \& Environmental Science and Engineering, Nelson Mandela African Institution of Science and Technology, \\ NM-AIST, Arusha, Tanzania
}

Email address:

mkalia@nm-aist.ac.tz (A. H. Mkali), Jasper.ijumba@nm-aist.ac.tz (J. Ijumba), karoli.njau@nm-aist.ac.tz (K. N. Njau)

To cite this article:

Ahamdi Habibu Mkali, Jasper Ijumba, Karoli Nicholas Njau. Effects of Wastewater Characteristics on Fish Quality from Integrated Wastewater Treatment System and Fish Farming in Urban Areas, Tanzania. Agriculture, Forestry and Fisheries.

Vol. 3, No. 4, 2014, pp. 292-298. doi: 10.11648/j.aff.20140304.21

\begin{abstract}
Availability of suitable water is one of the most important limiting factors for development of sustainable aquaculture in the urban areas. As a consequence, the use of wastewater effluents for aquaculture is on the rise in developing countries, Tanzania being one of the implementing country; quality of fish from such environments becomes questionable for human consumption. Clarius gariepinus were raised in selected Wastewater Stabilization Ponds (WSPs) at Moshi Municipal (Maturation two (M 2), four (M 4), six (M 6), fish pond (FP) and Lake Duluti (LD as Control site) for ninety days to investigate fish contamination (heavy metals and microbial) and body composition. Among all seven selected heavy metals $(\mathrm{Hg}, \mathrm{Cd}, \mathrm{Mo}, \mathrm{Cr}, \mathrm{As}, \mathrm{Zn}$ and $\mathrm{Pb})$ only four $(\mathrm{Hg}, \mathrm{Cd}, \mathrm{Cr}$ and $\mathrm{Zn})$ were detected in analyzed fish and water samples, while $(\mathrm{Pb}$, Mo and As) was below detection limits of X-Ray Fluorescence (Spectro xepos-EDXRF) analyzer. The results revealed that fish sample had higher concentration of detected metals than water samples from all treatments except for $\mathrm{Hg}$ of water sample from M2 and M4 was higher than fish sample and above the permissible limits by WHO. There was variation in crude protein and crude fat in analyzed fish samples from all treatments site. The fish reared in M4 contain higher percentage of crude protein (81.36) and crude fat (18.45) than other treatments. Escherichia coli and Staphylococcus aureus were detected in fish samples from all treatments with number of counts was within standards, while Salmonella spp was only present in M2. Results from this study reveals that with proper management, maturation ponds can be used for fish production but maturation two should be abandoned for fish farming due to high metals and microbial contamination. Public awareness on the dangers to which fish consumers from the site are exposed is highly suggested and purposeful mitigation measures of stopping all fishing activities in these sites is needed until further study on quality of indigenous fish accomplished.
\end{abstract}

Keywords: Wastewater Quality, Heavy Metal, Microbiological and Body Composition

\section{Introduction}

Water source is one of the most important limiting factors in the arid and semi-arid regions that can exhibit the development of sustainable aquaculture. As a consequence, the use of wastewater effluents for agriculture and aquaculture is on the rise in developing countires. Recycling waste water for agriculture and aquaculture is not new practice, it dates back more than a century in Germany (Kumar and Sierp, 2003). Recycled wastewater for agriculture and aquaculture production normally originated from household kitchen, cloth wash, bathroom shower, and other municipal sources (e.g., supermarkets, restaurants, offices and industries) (Mojid et al., 2010). Wastewater from those areas contains solid wastes, fecal matter, engine oil, grease, diesel, and harmful chemicals and microbes that not only affect the product produced but also the farmers and final user of the product (Mbuligwe and Kaseva, 2005). At Global levels it was shown that, least develeoped countries has los developed wastewater treatment system (Sato et al., 2013). It was suggested that an average of $8 \%$ of generated wastewater is treated in low-income countries when compared to that high-income countries on average treat $70 \%$ of the generated wastewater, followed by upper-middle-income countries $38 \%$, 
lower-middle-income countries 28\% (Sato et al., 2013)

Heavy metals is one of challenge in reusing of wastewater for aquaculture production, this is because they are non-degradable and often accumulate through trophic level causing a deleterious biological effects (Aktar et al., 2010). The accumulation of heavy metals in fish tissues is highly dependent upon the water concentration of heavy metals and exposure period, while environmental factors such as salinity, ph, hardness and temperature also play significant roles in metal accumulation (Nyirenda et al., 2013). Under certain environmental conditions heavy metals can accumulate up to toxic concentrations and cause ecological damage. In most cases fish is used as indicative factors in estimation of metal pollution in aquatic the aquatic system because they lie at the top of the aquatic food chain and may accumulate large amount of some metals from the water (Abdel-Baki et al., 2013). Clarius gariepinus is mostly selected organism in various study for heavy metal contamination due to its feeding beahaviour and bottom feeding habits (Obasohan et al., 2008), in addition they are able to tolerate adverse aquatic conditions where other cultivable fish species can not survive.

Contaminationa of heavy metal in fish flesh and its health hazard effects to the human gain more concern to food scientists. Almost all heavy metals are potentially harmful to most living organisms after exposure and adsorb certain level of it (Aktar et al., 2011). The most reported toxic heavy metals to human health from contaminated aquatic organisms are cadmium $(\mathrm{Cd})$, Mercury $(\mathrm{Hg})$ and Lead (Pb) (Omar, 2013) and some persistent organic pollutants (POPs) as a results of pollution from agriculture, industries, mining, household effluents and vector control (Polder et al. (2014); Mdegela et al. (2009). Among other effects, heavy metals may interfere with the major functions of the endocrine system of human and were termed endocrine disrupters. The study by Georgescu et al. (2011) demonstrated that heavy metals such as cadmium (Cd), arsenic (As), mercury (Hg), nickel (Ni), lead (Pb) and zinc ( $\mathrm{Zn})$ may exhibit endocrine-disrupting activity in animal experiments. It was said that in most of developing countries, human are highly exposed to chronic heavy metals pollution and the effects are not clear understood due to low knowledge on symptoms and medication (Nziku and Namkinga, 2013). Therefore investigation of contaminaion of fish with heavy metals that are highly toxic to human being is of great importance for taking appropriet measures to protect public health and the evironmental at large (Singh et al., 2012).

Use of recycled waste water in fish production may however, pose health risks to humans and aquatic organisms through possible introduction of pathogens (Abdul-Rahaman et al., 2012). Aquaculture products like other foods have hazards that may adversely affect the consumers' health. The production system also presents risks to public health and major health risks of aquaculture products are biological especially for the organisms produced in wastewater or water receiving animal and human wastes therefore; safety of consuming fish products from such environments becomes questionable (Abreu-Acosta and Vera, 2011). It was said that vast majority of outbreaks of food-related illness are due to pathogenic microorganism rather than to chemical or physical contaminants (Amagliani et al., 2012). Presence of faecal coliform in fish intended for human consumption may constitute a potential danger of causing disease (Ampofo and Clerk, 2010). Escherichia coli \& Staphylococcus aureaus and Salmonella are within group of pathogenic bacteria which cause food poisoning that lead to public health problem associated with fish and fishery products (Henson and Humphrey, 2009). Hence monitoring of these group of bacteria has been suggested as a measure of fish quality.

This study emphasized measurement of body composition, heavy metals (Mercury (Hg), Chromium (Cr), (Zn), Cadmium (Cd), Nickel (Ni), Mercury (Hg), Arsenic (As) and Molybdenum (Mo)) and Microbial contamination in the muscle tissues of fishes raised through integration of fish farming with wastewater treatment techonology at Moshi Municipal, Tanzania.

\section{Material and Methods}

This study was conducted in standing cages suspended in maturation ponds from March $16^{\text {th }}$ to June $20^{\text {th }}, 2014$ located at the Wastewater Treatment Plant of Moshi Urban Water Supply and Sanitation Authority, Moshi Municipal, Kilimanjaro, Tanzania. Total catchment area covers about 42 ha, while treatment area cover only 10.5 ha. The treatment plant has holding capacity of $45,000 \mathrm{~m}^{3}$ day $^{-1}$ but currently serve only $35,000 \mathrm{~m}^{3} \mathrm{day}^{-1}$. Treatment system has one anaerobic pond $(150 \times 55 \times 5 \mathrm{~m})$, two facultative ponds $(160 \times 50 \times 2.5 \mathrm{~m})$, six maturation ponds $(100 \times 50 \times 1.5 \mathrm{~m})$, constructed wetland $(50 \times 15 \times 1.5 \mathrm{~m})$ and one fish pond $(20 \times 10 \times 1.5 \mathrm{~m})$.

\subsection{Experimental Fish}

Catfish (Clarias gariepinus) fingerlings weighing 3-18 g, 6.8-13.6 cm height and tilapia (Oreochromis niloticus) fingerlings weighing 2-8 g, 5.3-8.4 cm height were obtained from Fish Hatchery Center, Sokoine University of Agriculture.

\subsection{Experimental Cages}

Ten standing cages $(2 \times 1 \times 1 \quad \mathrm{~m})$ were used for accomplishing the experiment. The standing cages had a supporting frame of tree pole extending $0.5 \mathrm{~m}$ below the cages floor to suspended it above the pond bottom and keep it away from the bottom sediment and maximize the water exchange. The mesh walls are attached to the upper part of this frame, a polyethylene net with a mesh size of $1 / 4$ inch was fixed inside cages and cleaned by brushing every two weeks to remove attached algal growth, the six cages were placed in a three maturation (M2, M4 and M6) ponds (measuring 
$100 \times 50 \mathrm{~m}$ and an average depth of $1.5 \mathrm{~m}$ ) having wastewater flowing from facultative ponds, two cages were place in a cemented fish pond (measured $20 \times 10 \mathrm{~m}$ and average depth of $1 \mathrm{~m}$ ) and two last cages were placed in the Lake Duruti.

\subsection{Experimental Design}

Fish were reared in five different water quality ranging from wastewater to clean water. Both African catfish and Tilapia were stocked at a rate of five fish $/ \mathrm{m}^{2}$ of water from each size 3-18 $\mathrm{g}$ for Catfish and 2-8 $\mathrm{g}$ for Tilapia for 90 days. Water analysis for heavy metals concentration $(\mathrm{Cd}, \mathrm{Pb}, \mathrm{Cr}$, As, $\mathrm{Zn}, \mathrm{Mo}$ and $\mathrm{Hg}$ ) were analyzed from each study site. Also, at the end of the experimental period the fish were harvested and analyzed for heavy metal concentration, microbiological load (Salmonella, E. coli, and Staphylococcus. aureus) and body composition (total fat and total protein).

\subsection{Water Sampling/Sample Preparation}

The water sample were filled in sample bottles in triplicate from each experimental sites. There after the sample fixed at $\mathrm{pH}$ of 2 by nitric acid and samples were kept refrigerated at $4{ }^{0} \mathrm{C}$ before being transferred to SEAMIC laboratory for heavy metals analysis.

\subsection{Fish Sampling/Sample Preparation}

The experimental fish were harvested from cages and immediately chilled before kept frozen at $-18{ }^{0} \mathrm{C}$ before gathered to the laboratory for further analytical procedures. Before analysis, frozen fish were thawed in warm clean water then de-headed and filleted using sharp knife. Head and fillet of fish were then dried over 24 hours at $80{ }^{\circ} \mathrm{C}$ in heraeus thermo scientific oven. The sample then grinded for 20 minutes at $180 \mathrm{rpm}$ using planetary mono mill (pulverisette 6) to get fine particles, the meal was used to make pellets after mixing with binder (starch). Pellets were inserted in X-Ray fluorescence (Spectro xepos -EDXRF) for analyzing the sample.

\subsection{Water Analysis for Heavy Metal}

Water samples in the bottles were shaken sufficiently for thorough mixing, and then $50 \mathrm{mls}$ aliquots were filtered on Watman No. 41 filter papers and quantitatively transferred into $50 \mathrm{mls}$ volumetric flask before aspiring directly into the Inductively Coupled Plasms for analysis of heavy metals according to Varian (1986).

\subsection{Fish Analysis}

\subsubsection{Heavy Metals Analysis}

The concentrations of the selected heavy metals $(\mathrm{Hg}, \mathrm{Pb}$, $\mathrm{Cr}$, As, Cd, Mo and $\mathrm{Zn}$ ) in fish flesh and head were determined using X-Ray Fluorescence analyzer.

\subsubsection{Nutritive Value Analysis of Fish}

Nutritive value of the sample flesh (crude protein and crude fat fat) were determined using Kjedahl Steam Distillation and Soxhlet methods respectively.

\subsubsection{Microbiological Analysis of Fish}

Microbial load on the fish flesh (Escherichia coli, Salmonella/Shigella spp, Staphylococcus aureus) were determined using TZS 731:2007, TZS 122:2007, TZS 125:2002/AM1:2007 test methods respectively

\subsection{Statistical Analysis}

The data were analyzed for significant differences $(\mathrm{P}<0.05)$ by Analysis of Variance (ANOVA) using computer Statistical Package for Social Sciences (SPSS) for windows (v.16.0). Determined differences were partitioned by the Least Significant Difference (LSD) at $\mathrm{P}=0.05$.

\section{Results Analysis}

\subsection{Water Analysis for Heavy Metals}

The concentration of $\mathrm{Cr}, \mathrm{Pb}, \mathrm{As}, \mathrm{Cd}, \mathrm{Zn}$ and $\mathrm{Mo}$ in water were significantly lower than WHO recommended standards while concentration of $\mathrm{Hg}$ in Maturation two was higher than the recommended WHO standards. The results were ellustrated in table 1 .

\subsection{Fish Analysis}

\subsubsection{Heavy Metals in Fish Flesh and Head}

The result ellustrated in table 2, show that Zinc and Chromium were detected from catfish harvested from all experimental sites with high levels of Zinc in head than fish flesh. There was variaton in level of Mercury and Cadmium in some experimental sites, while Lead, Molybdenum and Arsenic were not detected at all from all experimental sites.

\subsection{Nutritive Value Analysis of Fish}

\subsubsection{Crude Protein and Fatcontent in Fish}

The result in table 3 has shown that there have been variations in the levels of both crude protein and crude fat contents of the catfish flesh from different experimental sites. Catfish flesh from maturation pond 2 have a higher percentage of crude protein and crude fat contents, as compared to other experimental sites.It has shown that catfish reared in Maturation pond 6 contain lowest percentage of crude protein content than all other experimental sites, while crude fat content of those reared in fish pond was much lower than all other experimental sites.

\subsubsection{Microbialogical Analysis of Fish Flesh}

Results from table 4, flesh of C. Gariepinusraised in maturation two recorded the highest counts for all categories of microorganisms cultured, while those obtained from Lake Duluti recorded low counts for Salmonella/Shigella, Escherichia coli and Staphylococcus aureus. Samples from M 4, M 6, FP and LD recorded no counts for Salmonella spp. 
Table 1. Levels of heavy metals in water sample

\begin{tabular}{|c|c|c|c|c|c|c|}
\hline \multirow{2}{*}{ Heavy metal } & \multirow{2}{*}{ PL } & \multicolumn{5}{|l|}{ Site } \\
\hline & & M2 & M 4 & M 6 & FP & LD \\
\hline $\mathrm{Hg}\left(\mathrm{mg} \mathrm{l}^{-1}\right)$ & 0.1 & 1.26 & 0.16 & 0.1 & 0.08 & 0.08 \\
\hline $\mathrm{Pb}\left(\mathrm{mg} \mathrm{l}^{-1}\right)$ & 0.1 & $<0.01$ & $<0.01$ & $<0.01$ & $<0.01$ & $<0.01$ \\
\hline $\mathrm{Cd}\left(\mathrm{mg} \mathrm{l}^{-1}\right)$ & 0.1 & 0.1 & 0.04 & 0.03 & 0.02 & 0.03 \\
\hline $\operatorname{Mo}\left(\mathrm{mg} \mathrm{l}^{-1}\right)$ & 0.5 & $<0.01$ & $<0.01$ & $<0.01$ & $<0.01$ & $<0.01$ \\
\hline $\mathrm{Cr}\left(\mathrm{mg} \mathrm{l}^{-1}\right)$ & 1 & $<0.01$ & $<0.01$ & $<0.01$ & $<0.01$ & $<0.01$ \\
\hline As $\left(\mathrm{mg} \mathrm{l}^{-1}\right)$ & 0.05 & $<0.01$ & $<0.01$ & $<0.01$ & $<0.01$ & $<0.01$ \\
\hline $\mathrm{Zn}\left(\mathrm{mg} \mathrm{l}^{-1}\right)$ & 5 & 0.02 & 0.02 & 0.02 & 0.07 & 0.01 \\
\hline
\end{tabular}

PL: Permissible limits according to (WHO, 2006); M2: Maturation pond two; M4: Maturation pond four; M6: Maturation pond six; FP: Fish pond; LD: Lake Duluti

Table 2. Levels of heavy metals in catfish flesh and head

\begin{tabular}{|c|c|c|c|c|c|c|c|c|c|c|c|}
\hline \multirow{2}{*}{ Heavy metal } & \multirow{2}{*}{ PL } & \multicolumn{2}{|l|}{ M 2} & \multicolumn{2}{|l|}{ M 4} & \multicolumn{2}{|l|}{ M 6} & \multicolumn{2}{|l|}{ FP } & \multicolumn{2}{|l|}{ LD } \\
\hline & & Flesh & Head & Flesh & Head & Flesh & Head & Flesh & Head & Flesh & Head \\
\hline $\mathrm{Hg}\left(\mathrm{mg} \mathrm{kg}^{-1}\right)$ & 0.5 & 0.21 & 0.00 & 0.00 & 0.00 & 0.27 & 0.00 & 0.28 & 0.2 & 0.00 & 0.00 \\
\hline $\mathrm{Pb}\left(\mathrm{mg} \mathrm{kg}^{-1}\right)$ & 0.05 & 0.00 & 0.00 & 0.00 & 0.00 & 0.00 & 0.00 & 0.00 & 0.00 & 0.00 & 0.00 \\
\hline $\mathrm{Cd}\left(\mathrm{mg} \mathrm{kg}^{-1}\right)$ & 0.5 & 0.00 & 0.00 & 0.01 & 0.00 & 0.02 & 0.01 & 0.01 & 0.00 & 0.02 & 0.03 \\
\hline $\operatorname{Mo}\left(\mathrm{mg} \mathrm{kg}^{-1}\right)$ & 0.5 & 0.00 & 0.00 & 0.00 & 0.00 & 0.00 & 0.00 & 0.00 & 0.00 & 0.00 & 0.00 \\
\hline $\mathrm{Cr}\left(\mathrm{mg} \mathrm{kg}^{-1}\right)$ & 1.0 & 0.24 & 0.22 & 0.22 & 0.21 & 0.22 & 0.23 & 0.25 & 0.21 & 0.23 & 0.22 \\
\hline As $\left(\mathrm{mg} \mathrm{kg}^{-1}\right)$ & 0.05 & 0.00 & 0.00 & 0.00 & 0.00 & 0.00 & 0.00 & 0.00 & 0.00 & 0.00 & 0.00 \\
\hline $\mathrm{Zn}\left(\mathrm{mg} \mathrm{kg}^{-1}\right)$ & 60 & 22.54 & 43.893 & 26.14 & 52.73 & 25.98 & 51.51 & 21.95 & 38.24 & 36.98 & 48.17 \\
\hline
\end{tabular}

PL: Permissible limits (dry wt.) according to (Joint et al., 2007); M2: Maturation pond two; M4: Maturation pond four; M6: Maturation pond six; FP: Fish pond; LD: Lake Duluti

Table 3. Fish body composition analysis results for the fish flesh

\begin{tabular}{|c|c|c|c|c|c|}
\hline \multirow{2}{*}{ Chemical analysis } & \multicolumn{5}{|l|}{ Site } \\
\hline & M 2 & M 4 & M 6 & FP & LD \\
\hline Crude protein $(\% \mathrm{w} / \mathrm{w})$ & 73.86 & 81.36 & 61.25 & 70.28 & 57.94 \\
\hline Crude fat $(\% \mathrm{w} / \mathrm{w})$ & 15.78 & 18.45 & 15.94 & 15.73 & 15.36 \\
\hline
\end{tabular}

Table 4. Microbial count in catfish flesh

\begin{tabular}{|c|c|c|c|c|c|c|}
\hline \multirow{2}{*}{ Parameter } & \multirow{2}{*}{ Criteria } & \multicolumn{5}{|l|}{ Site } \\
\hline & & M 2 & M 4 & M 6 & FP & LD \\
\hline Salmonella spp (P.A/25) & Absent & Present & Absent & Absent & Absent & Absent \\
\hline E.coli Count $(\mathrm{mpn} / \mathrm{g})$ & $4 \times 10^{2}$ & $0.7 \times 10^{1}$ & $0.4 \times 10^{1}$ & $0.4 \times 10^{1}$ & $0.4 \times 10^{1}$ & $0.2 \times 10^{1}$ \\
\hline Staphylococcus aureus Count $(\mathrm{cfu} / \mathrm{g})$ & $1.0 \times 10^{3}$ & $<1.0 \times 10^{2}$ & $1.0 \times 10^{2}$ & $2.0 \times 10^{2}$ & $<1.0 \times 10^{2}$ & $<1.0 \times 10^{2}$ \\
\hline
\end{tabular}

M2: Maturation pond two; M4: Maturation pond four; M6: Maturation pond six; FP: Fish pond; LD: Lake Duluti

\section{Discussions}

Selected heavy metals detected from the present study was $\mathrm{Hg}, \mathrm{Cd}$, As and $\mathrm{Zn}$ while others were below the detected limits of the analyzing instrument. The concentration of $\mathrm{Hg}$ in maturation two was found to be above the (Joint et al., 2007) standards. Mercury concentration above the standard is found in M 2 except in the M 4, M 6 and fish pond wastewater which was due to the preliminary treatment it has undergone. The results in present study for other detected metals i.e $\mathrm{Cd}, \mathrm{Cr}$ and $\mathrm{Zn}$ was in line with Kihampa (2013), but lower than the findings from Mwegoha and Kihampa (2010).

The concentration of $\mathrm{Hg}$ found in the flesh and head of $C$. gariepinus harvested from M 2, M 6 and fish pond was ranging from $0.21-0.28 \mathrm{mg} \mathrm{kg}^{-1}$, these results was within the recommended level set by the standards (Joint et al.,
2007). The observed results was low when compared with the results observed by Kumar et al. (2011); and Malik et al. (2010); Nziku and Namkinga (2013). Even though the concentration of mercury discovered by this study is below the standard, consumption of catfish reared in M 2, M 6 and Fish pond is not recommended. Mercury is among of non-biodegradable metal, hence it tend to bio-accumulate and bio-magnify in fish tissues and remain in the fish till they are caught and use as food by humans Ernawati (2014)

Cadmium is a non-essential toxic metal, and may accumulate in humans from food chain magnification. Cadmium could be readily bio accumulated in lower portion of food chain and bio-concentrate in multiple organs of fish. The concentration of cadmium in the catfish flesh and head reared in M4, M6, fish pond and Lake Duluti was very low ranging from $0.01-0.03 \mathrm{mg} \mathrm{kg}^{-1}$ which was within the standards of 0.05 by (Joint et al., 2007). The observed value were comparable with suckermouth catfish's flesh from 
Ciliwung River however, lower than the species from East Kolkata wetlands (Kumar et al., 2011). Thus from the results, the fish is still safe to consume according to cadmium heavy metal standards because it still below the maximum standard declared by the regulatory agency.

The results, show concentration of chromium ranging from $0.21-0.25 \mathrm{mg} \mathrm{kg}^{-1}$ which is within the permissible limits (1 $\left.\mathrm{mg} \mathrm{kg}^{-1}\right)$ set by (FAO/NACA, 1999). The observations in present study was in line with findings by Obasohan et al. (2008) $\left(0.36-0.92 \mathrm{mg} \mathrm{kg}^{-1}\right)$, however the results was lower than the level by Bhuvaneshwari et al. (2012) of $4.3 \mathrm{mg} \mathrm{kg}^{-1}$ in fish muscle.

The results, show that the highest concentration $\mathrm{Zn}$ was $\left(52.73 \mathrm{mg} \mathrm{kg}^{-1}\right)$ in head of catfish from maturation pond number six and lowest was $\left(21.95 \mathrm{mg} \mathrm{kg}^{-1}\right)$ in flesh of catfish from fish pond. These values were lower than values observed by (Bhuvaneshwari et al. (2012) ranges from 45 $260 \mathrm{mg} \mathrm{kg}^{-1}$; Kumar et al. (2011) with value of $60.7 \mathrm{mg} \mathrm{kg}^{-1}$ )

These concentration differences of heavy metal between this study and others can be explained by considering aspects like concentration level of heavy metals in the surrounding environment, ecological needs, and rate of metabolism, feeding behavior of the fish, exposure time and seasonal variation. Although these value observed to lie within the permissible limits of Joint et al. (2007) they can reach dangerous trend if the sources of these metals are not controlled.

Proximate body composition conducted on the harvested fish from experimental sites of the present study showed higher nutritional composition in terms of crude protein (\%) and crude fat $(\%)$ (crude protein ranging from $81.36 \pm 5$ to $57.94 \pm 4.7$, crude fat from $18.45 \pm 1.1$ to $13.73 \pm 0.8$ ) compared to what observed by Tenkorang et al. (2012) on their study where crude protein was $65.72 \%$ and $65.36 \%$ while crude lipids was $6.31 \%$ and $6.01 \%$ from the fish reared in non-wastewater fish pond and wastewater-fed fish pond respectively. It was reported that the body composition of fish is influenced by chemical composition of the feed in use (Asdari et al., 2011). The higher body composition of the fish of the present study may be was due to combination of supplementary feed and natural diet which in together help the fish to synthesize tissue protein and fat.

The total number of Escherichia coli and Staphylococcus aureus bacterial count from flesh of catfish reared in $\mathrm{M} 2$ was $0.7 \times 10^{1}$ and $2.0 \times 10^{2} \mathrm{cfu} / \mathrm{g}$ respectively, this number fell within acceptable limits according to Emikpe et al. (2011) who said that the acceptable limit for mesophilic aerobic bacteria not exceeding $10^{6} \mathrm{cfu} / \mathrm{g}$. Salmonella spp was counted in M 2 which indicating the fish was not good for consumption. It was thought that, higher density of total aerobic bacteria found in the fish might be due to quick proliferation after harvesting and during transportation and storage of fish (Emikpe et al., 2011). Preservation in low quality ice, handling with contaminated hands could also be responsible for higher density of aerobic bacteria. Fish are very much susceptible to contamination with different bacteria because of their perishable protein content.

\section{Conclusion and Recommendations}

The results of this study revealed the quality of fish in terms of heavy metal and microbial contamination, body composition harvested from Municipal Wastewater Treatment Ponds (MWWTPs) that operated in Moshi. The findings indicate that despite of the conventional treatment of municipal wastewater by WSPs, the treated wastewater effluents are still contaminated with heavy metals. The levels of the heavy metals detected in fish are not remarkable to cause acute health consequences, but chronic adverse health effects due to prolonged bioaccumulation and long term exposure through fish consumption can be inevitable. Further studies need to focus on heavy metals and microbial contamination in indigenous fish within wastewater treatment plant. The microbial load of fish can be improved through regular disinfection of catching gears or working equipment, and brie immersion of caught fishes in disinfecting solution such as brine water to reduce the microbial load on the fish before storing at cold temperature or sold to the public. The public should be enlightened on the possibility of being susceptible to health problems when feeding a contaminated fish with heavy metals and harmful microorganisms.

\section{Acknowledgements}

The authors are very grateful to the work well done by Filbert Nyangwe, Mark Temba Gerald Kesi and Ms Lucy Emmanuel during sample and data collection. Mr Donny Jackob and Mrs Furaha Chuma from the Nyegezi Fish Quality laboratory and Tanzania Atomic Energy Commission are appreciated for their invaluable technical assistance laboratory extraction and heavy metals analysis in the laboratory. I remain ever indebted to the Commission of Science and Technology (COSTECH) and The Nelson Mandela African Institution of Science and Technology (NM-AIST) for funding this research

\section{References}

[1] Abdel-Baki A, Dkhil M and Al-Quraishy S. (2013) Bioaccumulation of some heavy metals in tilapia fish relevant to their concentration in water and sediment of Wadi Hanifah, Saudi Arabia. African Journal of Biotechnology 10: 2541-2547.

[2] Abdul-Rahaman I, Owusu-Frimpong $\mathrm{M}$ and Ofori-Danson PK. (2012) Sewage Fish Culture as an Alternative to Address the Conflict between Hunters and Hunting Communities in Northern Region. Journal of Agriculture and Sustainability 1.

[3] Abreu-Acosta N and Vera L. (2011) Occurrence and removal of parasites, enteric bacteria and fecal contamination indicators in wastewater natural reclamation systems in Tenerife-Canary Islands, Spain. Ecological Engineering 37: 496-503. 
[4] Aktar MW, Paramasivam M, Ganguly M, et al. (2010) Assessment and occurrence of various heavy metals in surface water of Ganga River around Kolkata: a study for toxicity and ecological impact. Environmental monitoring and assessment 160: 207-213.

[5] Aktar MW, Sengupta D and Chowdhury A. (2011) Occurrence of heavy metals in fish: a study for impact assessment in industry prone aquatic environment around Kolkata in India. Environmental monitoring and assessment 181: 51-61.

[6] Amagliani G, Brandi G and Schiavano G. (2012) Incidence and role of $<\mathrm{i}>$ Salmonella $</ \mathrm{i}>$ in seafood safety. Food Research International 45: 780-788.

[7] Ampofo JA and Clerk GC. (2010) Diversity of bacteria contaminants in tissues of fish cultured in organic waste-fertilized ponds: health implications. Open Fish Science Journal 3: 142-146.

[8] Asdari R, ALIYU - PAIKO M, Hashim R, et al. (2011) Effects of different dietary lipid sources in the diet for Pangasius hypophthalmus (Sauvage, 1878) juvenile on growth performance, nutrient utilization, body indices and muscle and liver fatty acid composition. Aquaculture Nutrition 17: 44-53.

[9] Bhuvaneshwari R, Mamtha N and PaneerSelvam B. (2012) Bioaccumulation of Metals in Muscle, Liver And Gills Of Six Commercial Fish Species at Anaikarai Dam of River Kaveri, South India. International Journal of PharmTech Research 2: 0976-4550.

[10] Emikpe B, Adebisi T and Adedeji O. (2011) Bacteria load on the skin and stomach of Clarias gariepinus and Oreochromis niloticus from Ibadan, South West Nigeria: public health implications. Journal of Microbiology and Biotechnology Research 1: 52-59.

[11] Ernawati Y. (2014). The analysis of the concentration of heavy metals cadmium, mercury and lead in the flesh of suckermouth catfish (Pterygoplichthys pardalis) in Ciliwung River, Indonesia. AACL Bioflux 7: 33-42.

[12] FAO/NACA WHO. (1999) Food safety issues associated with products from aquaculture: report of a joint FAO/NACA/WHO study group World Health Organization 883.

[13] Georgescu B, Georgescu C, Dărăban S, et al. (2011) Heavy metals acting as endocrine disrupters. Scientific Papers Animal Science and Biotechnologies 44: 89-93.

[14] Henson S and Humphrey J. (2009). The impacts of private food safety standards on the food chain and on public standard-setting processes. Rome: Food and Agriculture Organization of the United Nations (FAO).

[15] Joint F, Additives WECoF and Organization WH. (2007) Evaluation of certain food additives and contaminants: sixty-seventh report of the Joint FAO/WHO Expert Committee on Food Additives.

[16] Kihampa C. (2013) Heavy metal contamination in water and sediment downstream of municipal wastewater treatment plants, Dar es Salaam, Tanzania. International Journal of Environmental Sciences 3: 1407-1415.

[17] Kumar B, Mukherjee D, Kumar S, et al. (2011)
Bioaccumulation of heavy metals in muscle tissue of fishes from selected aquaculture ponds in east Kolkata wetlands. Annals of Biological Research 2: 125-134.

[18] Kumar MS and Sierp M. (2003) Integrated wastewater treatment and aquaculture production. Rural industries research \& Development Corporation. Extraído dehttp://www. rirdc. gov. au/reports/Ras/03-026. Pdf.

[19] Malik N, Biswas A, Qureshi T, et al. (2010) Bioaccumulation of heavy metals in fish tissues of a freshwater lake of Bhopal. Environmental monitoring and assessment 160: 267-276.

[20] Mbuligwe SE and Kaseva ME. (2005) Pollution and self-cleansing of an urban river in a developing country: A case study in Dar es Salaam, Tanzania. Environmental management 36: 328-342.

[21] Mdegela R, Braathen M, Pereka A, et al. (2009) Heavy metals and organochlorine residues in water, sediments, and fish in aquatic ecosystems in Urban and Peri-Urban areas in Tanzania. Water, air, and soil pollution 203: 369-379.

[22] Mojid M, Wyseure G, Biswas S, et al. (2010) Farmers' perceptions and knowledge in using wastewater for irrigation at twelve peri-urban areas and two sugar mill areas in Bangladesh. Agricultural Water Management 98: $79-86$.

[23] Mwegoha W and Kihampa C. (2010) Heavy metal contamination in agricultural soils and water in Dar es Salaam city, Tanzania. African Journal of Environmental Science and Technology 4: 763-769.

[24] Nyirenda M, Ramoabi TE, Dzoma BM, et al. (2013) A comparative study of the levels of heavy metals in dam water, borehole water and cattle serum around the Modimola dam of the Mafikeng, North West province, South Africa. Life 10.

[25] Nziku AJ and Namkinga L. (2013) Heavy metal pollution in the receiving environment of the University of Dar Es Salaam waste stabilization ponds. Journal of Biology and Life Science 4.

[26] Obasohan E, Oronsaye J and Eguavoen O. (2008) A Comparative Assessment of the Heavy Metal Loads in the Tissues of a Common Catfish (Clarias gariepinus) From Ikpoba and Ogba Rivers in Benin City. Nigeria Afr Sci 9: 13-23.

[27] Omar HE-DM. (2013) Seasonal variation of heavy metals accumulation in muscles of the African Catfish Clarias gariepinus and in River Nile water and sediments at Assiut Governorate, Egypt. Journal of Biology and Earth Sciences 3: B236-B248.

[28] Polder A, Müller M, Lyche J, et al. (2014) Levels and patterns of persistent organic pollutants (POPs) in tilapia $(<$ i $>$ Oreochromis $</$ i $>$ sp.) from four different lakes in Tanzania: Geographical differences and implications for human health. Science of the Total Environment 488: 252-260.

[29] Sato T, Qadir M, Yamamoto S, et al. (2013) Global, regional, and country level need for data on wastewater generation, treatment, and use. Agricultural Water Management 130: $1-13$. 
[30] Singh AK, Srivastava SC, Ansari A, et al. (2012) Environmental monitoring and health risk assessment of African catfish Clarias gariepinus (Burchell, 1822) cultured in rural ponds, India. Bulletin of environmental contamination and toxicology 89: 1142-1147.

[31] Tenkorang A, Yeboah-Agyepong M, Buamah R, et al. (2012)
Promoting sustainable sanitation through wastewater-fed aquaculture: a case study from Ghana. Water International 37: 831-842.

[32] WHO. (2006) WHO Guidelines for the Safe Use of Wastewater Excreta and Grey water: World Health Organization. 